\title{
The inhibiting effect of nitrate fertilisation on methane uptake of a temperate forest soil is influenced by labile carbon
}

\author{
Ann-Catrin Fender • Birgit Pfeiffer • Dirk Gansert • \\ Christoph Leuschner • Rolf Daniel • \\ Hermann F. Jungkunst
}

Received: 8 October 2011 /Revised: 13 December 2011 /Accepted: 23 December 2011 /Published online: 13 January 2012

(C) Springer-Verlag 2012

\begin{abstract}
Upland soils are the most important terrestrial sink for the greenhouse gas $\mathrm{CH}_{4}$. The oxidation of $\mathrm{CH}_{4}$ is highly influenced by reactive $\mathrm{N}$ which is increasingly added to many ecosystems by atmospheric deposition and thereby also alters the labile $\mathrm{C}$ pool in the soils. The interacting effects of soil $\mathrm{N}$ availability and the labile $\mathrm{C}$ pool on $\mathrm{CH}_{4}$ oxidation are not well understood. We conducted a laboratory experiment with soil columns consisting of homogenised topsoil material from a temperate broad-leaved forest to study the net $\mathrm{CH}_{4}$ flux under the combined or isolated addition of $\mathrm{NO}_{3}{ }^{-}$and glucose as a labile $\mathrm{C}$ source. Addition of $\mathrm{NO}_{3}{ }^{-}$and glucose reduced the net $\mathrm{CH}_{4}$ uptake of the soil by $86 \%$ and $83 \%$, respectively. The combined addition of both agents led to a nearly complete inhibition of $\mathrm{CH}_{4}$ uptake (reduction by $99.4 \%$ ). Our study demonstrates a close link between the availability of $\mathrm{C}$ and $\mathrm{N}$ and the rate of $\mathrm{CH}_{4}$ oxidation in temperate forest soils. Continued deposition of $\mathrm{NO}_{3}{ }^{-}$has the potential to reduce the sink strength of temperate forest soils for $\mathrm{CH}_{4}$.
\end{abstract}

A.-C. Fender $(\bowtie) \cdot$ D. Gansert $\cdot$ C. Leuschner

Plant Ecology and Ecosystems Research, University of Göttingen, Untere Karspüle 2,

37073 Göttingen, Germany

e-mail: afender@gwdg.de

B. Pfeiffer $\cdot$ R. Daniel

Genomic and Applied Microbiology, University of Göttingen, Grisebachstr. 8,

37077 Göttingen, Germany

H. F. Jungkunst

Landscape Ecology, University of Göttingen,

Goldschmidtstr. 5,

37077 Göttingen, Germany
Keywords $\mathrm{CH}_{4}$ uptake $\cdot \mathrm{NO}_{3}{ }^{-}$. Glucose $\cdot$ Soil moisture . Interaction of $\mathrm{C}$ and $\mathrm{N}$ cycles $\cdot \mathrm{N}$ deposition

\section{Introduction}

Methane $\left(\mathrm{CH}_{4}\right)$ has a 25 times higher global warming potential than carbon dioxide $\left(\mathrm{CO}_{2}\right)$. Its present concentration in the atmosphere has more than doubled from 715 to $1774 \mathrm{ppb}$ since pre-industrial times over the past 150 years (Forster et al. 2007). Hence, $\mathrm{CH}_{4}$ contributes about $15 \%$ to the present greenhouse effect of the long-lived greenhouse gases (Forster et al. 2007). Beside chemical oxidation in the troposphere (Crutzen 1991; Denman et al. 2007), biological oxidation in aerobic soils by methanotrophs and nitrifiers represents the second strongest absorber of atmospheric $\mathrm{CH}_{4}$ (Smith et al. 2000; Le Mer and Roger 2001; Denman et al. 2007). In a recent study, Dutaur and Verchot (2007) calculated the global $\mathrm{CH}_{4}$ sink of soils to $22.4 \mathrm{Tg}_{\text {year }}{ }^{-1}$. The $\mathrm{CH}_{4}$ uptake of soils in the temperate zone accounts for nearly half of this global sink $\left(10.4 \mathrm{Tg} \mathrm{CH}_{4}\right.$ year $\left.^{-1}\right)$. It is estimated that temperate forest soils contribute between 3 and 5.7 $\mathrm{Tg} \mathrm{CH}_{4}$ year $^{-1}$ to this sink (Curry 2007; Dutaur and Verchot 2007; Ishizuka et al. 2009). Therefore, any change in the $\mathrm{CH}_{4}$ sink strength of temperate forest soils as resulting from nitrogen $(\mathrm{N})$ deposition, liming or fertilisation activities, altered forest management or forest conversion is of global interest.

Over the past 200 years, temperate forest ecosystems have already received more than ten times higher anthropogenic $\mathrm{N}$ inputs through atmospheric deposition than in preindustrial times (Holland et al. 1999; Nadelhoffer et al. 1999; Galloway and Cowling 2002; Holland et al. 2005; Magnani et al. 2007). Many studies reported $\mathrm{N}$ deposition to be an important factor in the control of $\mathrm{CH}_{4}$ uptake by forest 
soils (Kasimir-Klemedtsson et al. 1997; Butterbach-Bahl et al. 1998). Liu and Greaver (2009) assumed that anthropogenic $\mathrm{N}$ addition reduces $\mathrm{CH}_{4}$ uptake by 3.9 to $9.1 \mathrm{Tg}$ $\mathrm{CH}_{4}$ year $^{-1}$ at the global scale. These figures compare well with the estimate of Dutaur and Verchot (2007) of a reduction by $17 \%$ to $40 \%$ of the $\mathrm{CH}_{4}$ sink strength. Due to the strong impact of $\mathrm{N}$ addition on $\mathrm{CH}_{4}$ uptake, intensive research in the laboratory and the field has addressed this topic (Goldman et al. 1995; Bradford et al. 2001b, 2001a; Jang et al. 2006; Borken and Brumme 2009; Bodelier 2011b). In various field studies (King and Schnell 1994a; Dobbie and Smith 1996; Steinkamp et al. 2001) and laboratory experiments (Adamsen and King 1993; Bender and Conrad 1994; Priemé and Christensen 1997; MacDonald et al. 1997), evidence was found for an inhibiting effect of ammonium $\left(\mathrm{NH}_{4}{ }^{+}\right)$fertilisation on $\mathrm{CH}_{4}$ oxidation in forest soils. A reduction of $\mathrm{CH}_{4}$ oxidation by $\mathrm{NH}_{4}{ }^{+}$addition has been explained by substrate competition between $\mathrm{NH}_{4}{ }^{+}$and $\mathrm{CH}_{4}$ at the binding sites of the catalysing enzyme $\mathrm{CH}_{4}$ monooxygenase (MMO) in the first step of the $\mathrm{CH}_{4}$ oxidation pathway (Bédard and Knowles 1989; Topp and Pattey 1997) resulting in enhanced $\mathrm{NH}_{4}{ }^{+}$oxidation. Other explanations are non-competitive effects exerted by the sideproduct hydroxylamine during $\mathrm{NH}_{4}{ }^{+}$oxidation (Mancinelli 1995), the production of toxic nitrite $\left(\mathrm{NO}_{2}^{-}\right)$during $\mathrm{NH}_{4}{ }^{+}$ oxidation (King and Schnell 1994b) and osmotic effects resulting from the formation of salts in the course of fertilisation (Dunfield and Knowles 1995; Gulledge and Schimel 1998). Furthermore, several studies reported a negative ef-

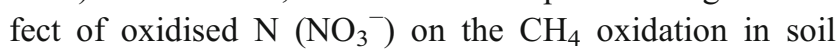
(Priemé and Christensen 1997; Wang and Ineson 2003; Reay and Nedwell 2004; Xu and Inubushi 2004; Ishizuka et al. 2009). This inhibiting effect has been explained by (a) the production of toxic concentrations of $\mathrm{NO}_{2}{ }^{-}$in anaerobic microsites (Adamsen and King 1993; Whalen 2000; Wang and Ineson 2003) or (b) the osmotic effect of salts (Dunfield and Knowles 1995; Gulledge and Schimel 1998). However, the underlying mechanisms of these non-competitive inhibiting effects of oxidised $\mathrm{N}$ on $\mathrm{CH}_{4}$ uptake are not yet sufficiently understood.

There is a recent debate on the influence of $\mathrm{N}$ addition on carbon (C) turnover and $\mathrm{C}$ stocks in forest soils (Magnani et al. 2007; Dezi et al. 2010; Janssens et al. 2010). According to de Vries et al. (2009), the C sequestration in European forest soils has increased as a consequence of the $\mathrm{N}$ deposition in the range of 5 to $23 \mathrm{~kg} \mathrm{C}$ per $\mathrm{kg} \mathrm{N}$ added. Thus, it is likely that a continuing high $\mathrm{N}$ input into forest soils will further increase the amount of labile $\mathrm{C}$. There is a need to study the consequences of increasing amounts of labile $\mathrm{C}$ and $\mathrm{N}$ in forest soils and their interaction on $\mathrm{CH}_{4}$ oxidation which is not well understood. Schnell and King (1995) studied the influences of $\mathrm{C}$ compounds as glucose, starch, yeast extract, methanol, ethanol, formate, acetate, malate or lactate on the $\mathrm{CH}_{4}$ oxidation of incubated forest soil. According to their results, these $\mathrm{C}$ compounds neither inhibit nor stimulate $\mathrm{CH}_{4}$ oxidation. However, the applied concentration may have not been high enough to influence the physiology and activity of the $\mathrm{CH}_{4}$ oxidising community; moreover, the interaction with $\mathrm{N}$ availability was not addressed.

In this study, we focused on the effects of $\mathrm{NO}_{3}{ }^{-}$fertilisation in combination with the application of labile $\mathrm{C}$ (glucose) on the $\mathrm{CH}_{4}$ uptake of a deciduous forest soil. We tested the hypotheses that (1) high $\mathrm{NO}_{3}{ }^{-}$input leads to a relevant reduction in the $\mathrm{CH}_{4}$ uptake of the forest soil, (2) glucose neither enhances nor inhibits $\mathrm{CH}_{4}$ uptake when added alone, but (3) in combination with $\mathrm{NO}_{3}{ }^{-}$, it increases the inhibiting effect of $\mathrm{NO}_{3}{ }^{-}$on $\mathrm{CH}_{4}$ uptake.

\section{Materials and methods}

Soil characteristics and soil sampling

The soil used for the experiment was sampled in a mixed broad-leaved temperate forest in Hainich National Park, Thuringia, Germany $\left(51^{\circ} 04^{\prime} \mathrm{N} 10^{\circ} 30^{\prime} \mathrm{E}\right)$ and was immediately prepared for incubation. At the sampling site, the dominating tree species are Fagus sylvatica L., Fraxinus excelsior L., Tilia cordata Mill., Tilia platyphyllos Scop., Carpinus betulus L., Acer pseudoplatanus L. and Acer platanoides L. The soil type is a Stagnic Luvisol (IUSS Working Group WRB 2007) of silty texture containing $1.8 \%$ sand, $80.2 \%$ silt and $18.1 \%$ clay. The sampled soil was free of carbonate $\left(<0.02 \%\right.$ of $\left.\mathrm{C}_{\text {total }}\right)$, had a $\mathrm{pH}(\mathrm{KCl})$ of 3.8 and a base saturation of $22.9 \%$. Material of the upper 0 to $10 \mathrm{~cm}$ of the mineral soil was collected, excluding litter material. After collecting the soil material, it was homogenised by passing it through a $5-\mathrm{mm}$ sieve.

\section{Experimental setup}

For the main experiment, 16 Plexiglass cylinders $(50 \mathrm{~cm}$ in height, $17 \mathrm{~cm}$ in diameter) were used and each filled with $4 \mathrm{~kg}$ of the freshly sieved soil. The water content at the start was $22.7 \%$ of the fresh weight. The columns were placed in a random arrangement in the laboratory. A supplementary experiment with 16 additional soil columns of the same dimensions and treated alike was conducted to (1) repeat the findings of the main experiment as well as to (2) exclude possible other effects like proposed inhibitory effects of salt addition and to (3) to have a control without labile $\mathrm{C}$ addition. Before the start of the main experiment, we kept the incubated soil for a period of 62 days under laboratory conditions to equilibrate the microbial soil community to the climatic conditions and to balance the gas exchange after 
disturbing the natural soil structure. After this pre-experimental phase, the experiment with two treatments (addition of $\mathrm{NO}_{3}{ }^{-}$ and glucose) lasted for another 62 days with three experimental phases (first, second and third $\mathrm{N}$-fertilisation phase) being distinguished (days 1-20, 21-41 and 42-62, respectively). In the main experiment, the $\mathrm{N}$ treatment was replicated eight times. The effect of $\mathrm{C}$ addition on $\mathrm{CH}_{4}$ was interpreted in comparison to the fluxes of the respective $\mathrm{N}$ treatment before $\mathrm{C}$ addition. At day 0 of the experiment (start of first $\mathrm{N}$ fertilisation phase), day 20 (start of second N-fertilisation phase) and day 41 (start of third $\mathrm{N}$-fertilisation phase), eight randomly chosen soil columns were fertilised with a $\mathrm{KNO}_{3}$ solution in deionised water with an equivalent of $200 \mathrm{~kg} \mathrm{~N} \mathrm{ha}^{-1}$. The amount of added water was adjusted to reach a water-filled pore space (WFPS) level of $80 \%$. At day 42 (start of third N-fertilisation phase), all 16 soil columns were additionally treated with a glucose solution (equivalent to $9,419 \mathrm{~kg} \mathrm{C} \mathrm{ha}^{-1}$ ) to simulate unlimited supply of labile $\mathrm{C}$ in the soil (both in the $\mathrm{N}$-fertilised and the untreated control columns). The addition of $\mathrm{N}$ and $\mathrm{C}$ increased the total $\mathrm{N}$ $\left(\mathrm{N}_{\text {total }}\right)$ and organic $\mathrm{C}\left(\mathrm{C}_{\text {org }}\right)$ pools in the soil columns in comparison to the initial $\mathrm{N}_{\text {total }}$ and $\mathrm{C}_{\text {org }}$ contents by absolute amounts of $7.7 \%$ and $8.0 \%(\mathrm{~N})$ and by $33.8 \%$ and $36.0 \%(\mathrm{C})$ on day 42 of the experiment in the control and the $\mathrm{N}$-fertilised columns, respectively.

In the supplementary experiment with fourfold replication, we examined the response of $\mathrm{CH}_{4}$ uptake to the addition of either $\mathrm{KNO}_{3}\left(\mathrm{NO}_{3}{ }^{-}\right.$source), $\mathrm{K}_{2} \mathrm{SO}_{4}$ (to test for effects of high $\mathrm{K}$ concentrations) or glucose (as a labile $\mathrm{C}$ source) using the same amounts of $\mathrm{N}, \mathrm{K}$ and $\mathrm{C}$ (200 kg N ha ${ }^{-1}$, $552 \mathrm{~kg} \mathrm{~K} \mathrm{ha}{ }^{-1}$, 9,419 kg C ha ${ }^{-1}$, respectively) and the same soil and cultivation conditions as in the main experiment. Furthermore, the initial soil conditions (apart from a higher $\mathrm{C}_{\text {org }}$ concentration, Table 2) and all analytical procedures were identical to those in the main experiment. The goal of the supplementary experiment with duration of 21 days was to compare the effects of $\mathrm{KNO}_{3}$ and $\mathrm{K}_{2} \mathrm{SO}_{4}$ and to study the effect of a labile $\mathrm{C}$ source independent from the $\mathrm{NO}_{3}{ }^{-}$effect. This additional experiment also served for measuring the $\mathrm{NH}_{4}{ }^{+}$concentrations in the soil after $\mathrm{NO}_{3}{ }^{-}$ addition because these data were lost in the main experiment due to technical shortcomings.

The soil columns were installed in a greenhouse with $14 \mathrm{~h}$ of low daylight (100 $\mu \mathrm{mol} \mathrm{m} \mathrm{m}^{-2} \mathrm{~s}^{-1}$ PPFD; OSRAM cool white, Lightcolor 840, Munich, Germany). The waterfilled pore space was measured every week by weighing the soil columns. The pore volume and the water-filled pore space were calculated by assuming a particle density of $2.65 \mathrm{~g} \mathrm{~cm}^{-3}$ (Schlichting et al. 1995) and by referring to the measured soil bulk density at the experiment's beginning. The soil temperature of each soil column was measured at a depth of $7.5 \mathrm{~cm}$ and a horizontal distance to the column edge of $3 \mathrm{~cm}$ using NTC thermistors (Epcos, Munich, Germany) that were logged in 15-min intervals with a CR10 data logger (Campbell Scientific Inc., UT, USA). The soil temperature did not differ between the treatments, but decreased slightly by $3^{\circ} \mathrm{C}$ over the course of the experiment (mean of $22.8 \pm 0.2^{\circ} \mathrm{C}$ in the $\mathrm{N}$-fertilised and the control treatment).

\section{Chemical soil analysis}

Before the start of the experiment, we analysed five replicate samples for the chemical properties of soil (Table 1). The $\mathrm{pH}$ $(\mathrm{KCl})$ was analysed in a suspension of $10 \mathrm{~g}$ soil in $1 \mathrm{M} \mathrm{KCl}$ solution using a Vario $\mathrm{pH}$ meter (WTW GmbH, Weilheim, Germany). The cation exchange capacity (CEC) of the soil was measured by percolating five samples of $2 \mathrm{~g}$ fresh soil with $0.2 \mathrm{M} \mathrm{BaCl}$. The percolates were analysed with an ICP-AES (Optima 3000 XL, PerkinElmer, MA, USA). The base saturation was calculated as the percentage of base cations ( $\mathrm{Na}, \mathrm{K}, \mathrm{Ca}$ and $\mathrm{Mg}$ ) in CEC. The bulk density of the soil material in the columns was determined using steel cores with a defined volume of $100.93 \mathrm{~cm}^{3}$. Before and after drying the soil cores at $105^{\circ} \mathrm{C}$ for $24 \mathrm{~h}$, the soil was weighed, and the bulk density of the dry material was calculated. At day 0 of the fertilisation experiment, the bulk density of the homogenised material was $1.05 \pm 0.02 \mathrm{~g} \mathrm{~cm}^{-3}$. The particle size distribution was determined with the sieving and pipette method (Schlichting et al. 1995). The concentrations of organic $\mathrm{C}\left(\mathrm{C}_{\text {org }}\right)$ and total $\mathrm{N}\left(\mathrm{N}_{\text {total }}\right)$ were analysed with a $\mathrm{C} / \mathrm{N}$ analyzer (Vario EL, Elementar, Hanau, Germany). The concentrations of $\mathrm{N}-\mathrm{NO}_{3}{ }^{-}$and $\mathrm{N}-$ $\mathrm{NH}_{4}{ }^{+}$in $\mathrm{mg} \mathrm{kg}^{-1} \mathrm{dw}$ were measured by extracting $8 \mathrm{~g}$ fresh soil with $0.5 \mathrm{M} \mathrm{K}_{2} \mathrm{SO}_{4}$ solution (ratio of wet soil mass to solution, 1:3) within the following 2 to $3 \mathrm{~h}$ after collecting the soil. The samples were shaken for $1 \mathrm{~h}$ and passed through folded filters (FT-4-303-150, Sartorius Stedim, Aubagne, France). The $\mathrm{NO}_{3}{ }^{-}$and $\mathrm{NH}_{4}{ }^{+}$concentrations of the filtered extracts were analysed by continuous flow injection colorimetry (SAN+Continuous Flow Analyzer, Skalar Instruments, Breda, The Netherlands). The $\mathrm{NO}_{3}{ }^{-}$ concentrations were determined with the copper-cadmiumreduction method (ISO method 13395), and those of $\mathrm{NH}_{4}{ }^{+}$ with the Berthelot reaction method (ISO method 11732).

At day 0 and at the end of the experiment, soil solution was sampled from the soil column by irrigating the soil with $500 \mathrm{ml}$ of distilled water. The percolating water was passed through filter papers (MN 85/70 BF, Macherey-Nagel, Düren, Germany) and the soil solution analysed with the DOC analyser (Dimatoc 100, Dimatec, Essen, Germany) to measure the concentration of dissolved organic $\mathrm{C}$. The concentration of $\mathrm{NO}_{3}{ }^{-}$in the soil solution was analysed by ion chromatography (761 Compact IC, Metrohm, Herisau, Switzerland). 
Table 1 Selected chemical parameters in the soil solution of the columns of the N-fertilised and the unfertilised control treatment in different phases of the experiment (means $\pm 1 \mathrm{SE}$ of each eight columns)

\begin{tabular}{|c|c|c|c|c|c|}
\hline \multirow[t]{2}{*}{ Experimental phase } & \multirow[t]{2}{*}{ Day 0} & Unfertilised control (N0) & $\mathrm{N}$-fertilised (N1) & Unfertilised control (N0) & $\mathrm{N}$-fertilised (N1) \\
\hline & & \multicolumn{2}{|l|}{ Day 41 (without glucose) } & \multicolumn{2}{|l|}{ Day 62 (glucose added) } \\
\hline $\mathrm{pH}(\mathrm{KCl})$ & $3.82 \pm 0.03$ & $3.84 \pm 0.08 \mathrm{aA}$ & $4.23 \pm 0.06 \mathrm{bA}$ & $4.49 \pm 0.07 \mathrm{aB}$ & $5.63 \pm 0.16 \mathrm{bB}$ \\
\hline $\mathrm{C}_{\text {org }}\left[\mathrm{g} \mathrm{kg}^{-1} \mathrm{dw}\right]$ & $19.84 \pm 0.44$ & $20.44 \pm 0.37 \mathrm{aA}$ & $19.20 \pm 0.25 \mathrm{bA}$ & $22.99 \pm 0.58 \mathrm{aB}$ & $22.62 \pm 0.28 \mathrm{aB}$ \\
\hline $\mathrm{N}_{\text {total }}\left[\mathrm{g} \mathrm{kg}^{-1} \mathrm{dw}\right]$ & $1.89 \pm 0.03$ & $2.08 \pm 0.03 \mathrm{aA}$ & $2.40 \pm 0.08 \mathrm{bA}$ & $1.99 \pm 0.01 \mathrm{aA}$ & $2.42 \pm 0.09 \mathrm{bA}$ \\
\hline $\mathrm{C} / \mathrm{N}\left[\mathrm{g} \mathrm{g}^{-1}\right]$ & $10.50 \pm 0.19$ & $9.85 \pm 0.10 \mathrm{aA}$ & $8.02 \pm 0.17 \mathrm{bA}$ & $11.52 \pm 0.18 \mathrm{aB}$ & $9.41 \pm 0.30 \mathrm{bB}$ \\
\hline $\mathrm{NO}_{3}^{-}\left[\mathrm{mg} \mathrm{Nkg}^{-1} \mathrm{dw}\right]$ & $6.39 \pm 0.28$ & ND & ND & $0.60 \pm 0.80 \mathrm{a}$ & $35.78 \pm 5.70 \mathrm{~b}$ \\
\hline $\mathrm{NH}_{4}^{+}\left[\mathrm{mg} \mathrm{Nkg}^{-1} \mathrm{dw}\right]$ & $7.85 \pm 0.28$ & ND & ND & $1.53 \pm 0.32 \mathrm{a}$ & $34.50 \pm 4.59 \mathrm{~b}$ \\
\hline $\mathrm{DOC}\left[\mathrm{mg} \mathrm{l}^{-1}\right]$ & $19.4 \pm 1.91$ & ND & ND & $515.3 \pm 89.9 \mathrm{a}$ & $273.2 \pm 51.7 b$ \\
\hline $\mathrm{NO}_{3}{ }^{-}\left[\mathrm{mg} \mathrm{l}^{-1}\right]$ & $9.6 \pm 3.50$ & ND & ND & $30.5 \pm 23.6 \mathrm{a}$ & $363.35 \pm 114.7 \mathrm{a}$ \\
\hline
\end{tabular}

Day 0 refers to the start of the experiment; day 41 is 6 weeks after the first $\mathrm{N}$ fertilisation and day 62 is 3 weeks after the third $\mathrm{N}$ fertilisation combined with glucose addition. Lower case letters indicate significant differences between the $\mathrm{N}$-fertilised and the control treatment within a given experimental phase $(P<0.05$, Wilcoxon $U$-test); different upper case letters indicate significant differences between columns before and after glucose addition $(P<0.05$, Wilcoxon signed rank test $)$

$N D$ parameter not detected

\section{Gas flux analysis}

Gas fluxes of $\mathrm{CH}_{4}$ at the soil surface were measured three times per week in the headspace volume of soil columns. The headspace volume in the Plexiglass columns was $8.6 \mathrm{~L}$. The chambers were closed for $1 \mathrm{~h}$. At 0, 20, 40 and $60 \mathrm{~min}$ elapsed time after lid closure, gas samples were taken from the chamber headspace by flushing gas-tight $50-\mathrm{ml}$ sample syringes with headspace air, using a needle and two threeway valves. The gas concentrations were analysed by a computer-controlled gas chromatographic system with a flame ionization detector for $\mathrm{CH}_{4}$ (Shimadzu GC-14B, Kyoto, Japan). A detailed description of the gas chromatograph was given by Loftfield et al. (1997). The gas fluxes were calculated from the linear increase of gas concentration, which was measured during the chamber emplacement.

\section{Data analysis}

Statistical analyses were performed using SAS 9.1 software (Statistical Analysis System, SAS Institute Inc., Cary, USA). Cumulative gas fluxes were calculated by summing up all measurements for each column considering the number of measurements and the corresponding duration of the measuring phase. Frequency distributions were tested for normality with the Shapiro-Wilk test. One-way GLM with the TukeyKramer test was used to identify significant differences among the $\mathrm{N}$-treatment means for cumulative $\mathrm{CH}_{4}$ fluxes and soil properties showing normal distribution. Not normaldistributed soil parameters were analysed with the Wilcoxon $U$-test. Differences among normal-distributed $\mathrm{CH}_{4}$ flux data of the different $\mathrm{C}$ treatments were assessed with the paired $t$ test. The Wilcoxon signed rank test was used to identify differences between the $\mathrm{C}$ treatments in not normal-distributed soil parameters (this single test was carried out with the $\mathrm{R}$ statistical package, version 2.11.1, R Foundation for Statistical Computing, Vienna, Austria). Linear regression analysis was conducted to relate $\mathrm{CH}_{4}$ flux to WFPS. For all analyses, significance was determined at $P<0.05$.

\section{Results}

Physical and chemical soil characteristics

Important chemical properties of the soil in the columns before the start of the experiment (day 0), at the end of the second $\mathrm{N}$ fertilisation phase (day 41) and 3 weeks after the combined application of $\mathrm{N}$ and $\mathrm{C}$ (day 62) are listed in Table 1. At the end of the second $\mathrm{N}$ fertilisation (day 41) and the end of the third experimental phase (combined addition of $\mathrm{N}$ and glucose, day 62$)$, the $\mathrm{pH}(\mathrm{KCl})$ in the $\mathrm{N}$-fertilised columns was significantly higher (by 0.4 and $1.1 \mathrm{pH}$ units, respectively) than in the unfertilised control. The glucose application strongly increased the $\mathrm{pH}$ by 0.7 (control) and 1.4 units ( $\mathrm{N}$-fertilised) compared with the corresponding $\mathrm{N}$ treatment before glucose was applied. At the $21^{\text {st }}$ and $42^{\text {nd }}$ day of the experiment (with the addition of $\mathrm{N}$ or $\mathrm{N}$ and $\mathrm{C}$ ), the WFPS was adjusted to approximately $80 \%$ (Fig. 1a). Subsequently, WFPS gradually declined due to soil evaporation with a slope of $-1.53 \pm 0.22 \% \mathrm{~d}^{-1}$ in the unfertilised soil columns and $-1.53 \pm 0.24 \% \mathrm{~d}^{-1}$ in the fertilised columns.

The effect of $\mathrm{NO}_{3}{ }^{-}$, glucose and $\mathrm{K}_{2} \mathrm{SO}_{4}$ on $\mathrm{C}_{\text {org }}$ and the mineral $\mathrm{N}$ concentration in the soil was investigated in the supplementary experiment (Table 2). The addition of $\mathrm{KNO}_{3}$ increased the $\mathrm{NO}_{3}{ }^{-}$and $\mathrm{NH}_{4}{ }^{+}$concentrations in the soil 
Fig. $1 \mathrm{CH}_{4}$ uptake and waterfilled pore space of the soil (WFPS) in soil columns containing forest soil, either fertilised with $\mathrm{NO}_{3}{ }^{-}$or unfertilised control during the experiment of 62 days duration. Given are mean values $\pm 1 \mathrm{SE}$ of each eight columns per $\mathrm{N}$-treatment. The $\mathrm{N}$-fertilization consisted of a total addition of $200 \mathrm{~kg} \mathrm{~N}$ $\mathrm{ha}^{-1}$ year ${ }^{-1}$ given as $\mathrm{KNO}_{3}$ on three occasions (first to third fertilisation). On day 41 of the experiment, all columns received additionally a glucose solution (equivalent to 9,419 $\mathrm{kg} \mathrm{C} \mathrm{ha}^{-1}$ ) as a labile C source

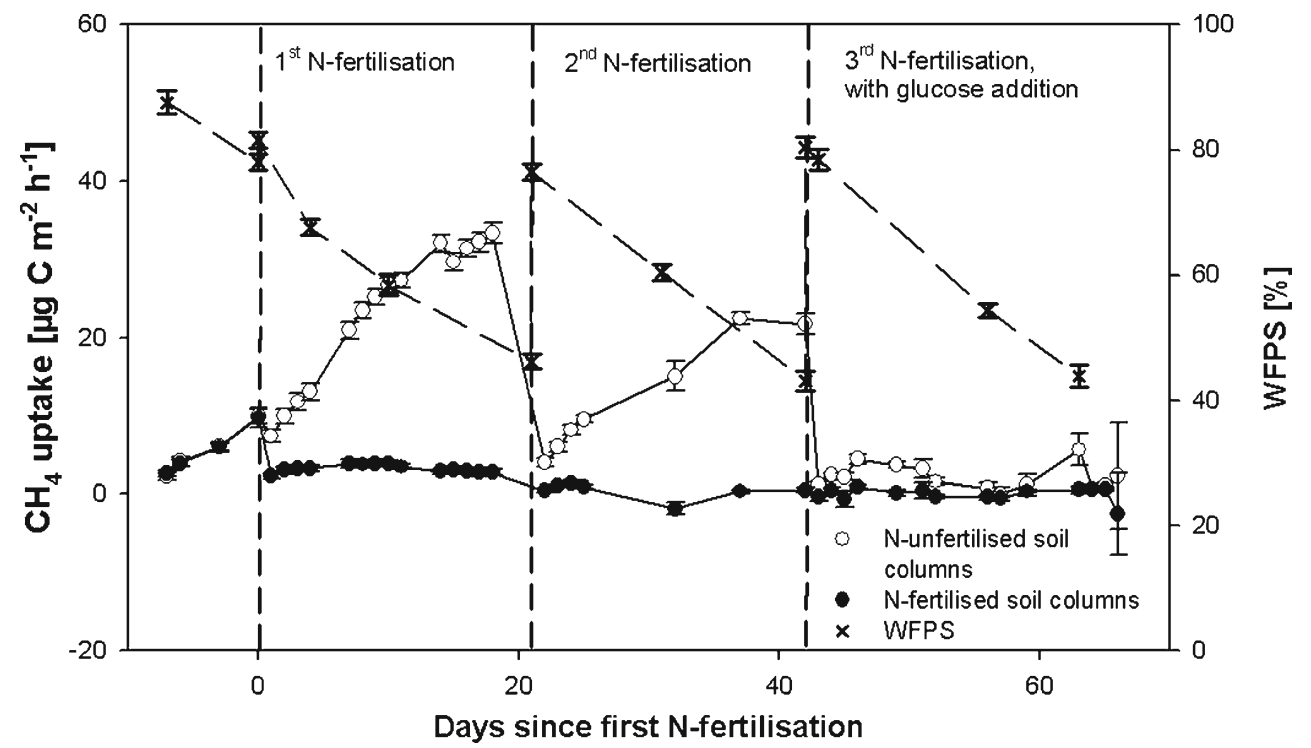

columns by $891 \%$ and $244 \%$, respectively. $\mathrm{K}_{2} \mathrm{SO}_{4}$ increased the $\mathrm{NO}_{3}{ }^{-}$and $\mathrm{NH}_{4}{ }^{+}$concentrations in the soil by $243 \%$ and $134 \%$, respectively. Glucose led to a significant increase of $\mathrm{C}_{\mathrm{org}}$ and a decline by $81 \%$ and $47 \%$ of $\mathrm{NO}_{3}{ }^{-}$and $\mathrm{NH}_{4}{ }^{+}$, respectively.

\section{$\mathrm{CH}_{4}$ fluxes}

During the first phase of the main experiment, the unfertilised control columns showed enhanced uptake of $\mathrm{CH}_{4}$ with declining WFPS. Maximum uptake (33.31 $1.36 \mu \mathrm{g}$ $\mathrm{C} \mathrm{m}^{-2} \mathrm{~h}^{-1}$ ) was measured at day 17 when WFPS had dropped to $49.50 \pm 1.64 \%$. In contrast, $\mathrm{NO}_{3}{ }^{-}$fertilisation reduced $\mathrm{CH}_{4}$ uptake considerably (Fig. 1). The $\mathrm{CH}_{4}$ uptake of the fertilised soil remained constantly low at $3.23 \pm 0.14 \mu \mathrm{g} \mathrm{C} \mathrm{m}^{-2} \mathrm{~h}^{-1}$ during the first experimental phase. In the second phase of the experiment, the maximum uptake of the unfertilised soil was $22.45 \pm$ $0.74 \mu \mathrm{g} \mathrm{m} \mathrm{m}^{-2} \mathrm{~h}^{-1}$. In the $\mathrm{N}$-fertilised soil columns, the second $\mathrm{N}$ application led to an even stronger inhibition of $\mathrm{CH}_{4}$ uptake than during the first phase. The first and second $\mathrm{NO}_{3}{ }^{-}$addition significantly reduced the cumulative $\mathrm{CH}_{4}$ uptake of the N- fertilised soil columns by $86 \%$ in the first and by $97 \%$ in the second phase compared with the unfertilised columns (Fig. 2).

Glucose application also led to a large reduction in $\mathrm{CH}_{4}$ uptake with average rates of only $2.41 \pm 1.70 \mu \mathrm{g}$ $\mathrm{C} \mathrm{m}^{-2} \mathrm{~h}^{-1}$ during the third phase. The cumulative $\mathrm{CH}_{4}$ uptake after glucose application was significantly lower in both the unfertilised control and in the $\mathrm{N}$-fertilised columns than in the first and second experimental phases before glucose application (Fig. 2). The glucose addition inhibited $\mathrm{CH}_{4}$ uptake to a similar extent (by $83 \%$ ) as did the first $\mathrm{NO}_{3}{ }^{-}$ addition. After combined $\mathrm{NO}_{3}{ }^{-}$and glucose addition in the third phase, the $\mathrm{CH}_{4}$ uptake was almost completely suppressed (reduction by $99.4 \%$ compared with the uptake of the control during the first phase, Fig. 2).

In the unfertilised control treatment of the main experiment, we found a strong negative correlation between $\mathrm{CH}_{4}$ uptake and WFPS with a large slope factor (higher $\mathrm{CH}_{4}$ uptake at lower soil moisture) in the first and second phase of the experiment $\left(R^{2}=0.679\right.$ and 0.788 , respectively, Fig. 3). After adding $\mathrm{NO}_{3}{ }^{-}$in the fertilised treatment, this relationship had a much smaller slope (first phase $R^{2}=0.14$ ),

Table 2 Chemical properties of the soil before (Day 0) and 21 days after the addition of $\mathrm{KNO}_{3}, \mathrm{~K}_{2} \mathrm{SO}_{4}$ or glucose compared with the control treatment in the supplementary experiment (means $\pm 1 \mathrm{SE}, n=4$ )

\begin{tabular}{llllll}
\hline & Day 0 & Control & $\mathrm{KNO}_{3}$ & $\mathrm{~K}_{2} \mathrm{SO}_{4}$ & Glucose \\
\hline $\mathrm{pH}(\mathrm{KCl})$ & $\mathrm{ND}$ & $4.32 \pm 0.11 \mathrm{a}$ & $4.15 \pm 0.09 \mathrm{a}$ & $4.12 \pm 0.07 \mathrm{a}$ & $4.20 \pm 0.04 \mathrm{a}$ \\
$\mathrm{C}_{\text {org }}\left[\mathrm{g} \mathrm{kg}^{-1} \mathrm{dw}\right]$ & $29.20 \pm 0.55$ & $29.00 \pm 0.23 \mathrm{ab}$ & $27.61 \pm 0.54 \mathrm{a}$ & $29.00 \pm 0.23 \mathrm{ab}$ & $32.8 \pm 1.76 \mathrm{~b}$ \\
$\mathrm{~N}_{\text {total }}\left[\mathrm{g} \mathrm{kg}^{-1} \mathrm{dw}\right]$ & $2.00 \pm 0.02$ & $1.95 \pm 0.03 \mathrm{a}$ & $2.02 \pm 0.05 \mathrm{a}$ & $1.96 \pm 0.01 \mathrm{a}$ & $1.89 \pm 0.02 \mathrm{a}$ \\
$\mathrm{C} / \mathrm{N}\left[\mathrm{g} \mathrm{g}^{-1}\right]$ & $14.69 \pm 0.32$ & $14.91 \pm 0.15 \mathrm{a}$ & $13.70 \pm 0.16 \mathrm{a}$ & $14.80 \pm 0.08 \mathrm{a}$ & $17.32 \pm 0.89 \mathrm{~b}$ \\
$\mathrm{~N}-\mathrm{NO}_{3}^{-}\left[\mathrm{mg} \mathrm{kg}^{-1} \mathrm{dw}\right]$ & $3.27 \pm 0.61$ & $5.07 \pm 3.00 \mathrm{ab}$ & $45.15 \pm 2.44 \mathrm{c}$ & $12.34 \pm 1.07 \mathrm{~b}$ & $0.94 \pm 0.81 \mathrm{a}$ \\
$\mathrm{N}-\mathrm{NH}_{4}{ }^{+}\left[\mathrm{mg} \mathrm{kg}^{-1} \mathrm{dw}\right]$ & $4.79 \pm 0.25$ & $3.96 \pm 1.86 \mathrm{a}$ & $9.65 \pm 0.85 \mathrm{~b}$ & $5.29 \pm 0.77 \mathrm{a}$ & $2.10 \pm 1.50 \mathrm{a}$ \\
\hline
\end{tabular}

Lower case letters indicate significant differences between the four treatments $(P<0.05$, Wilcoxon $U$-test $)$

$N D$ parameter not detected 


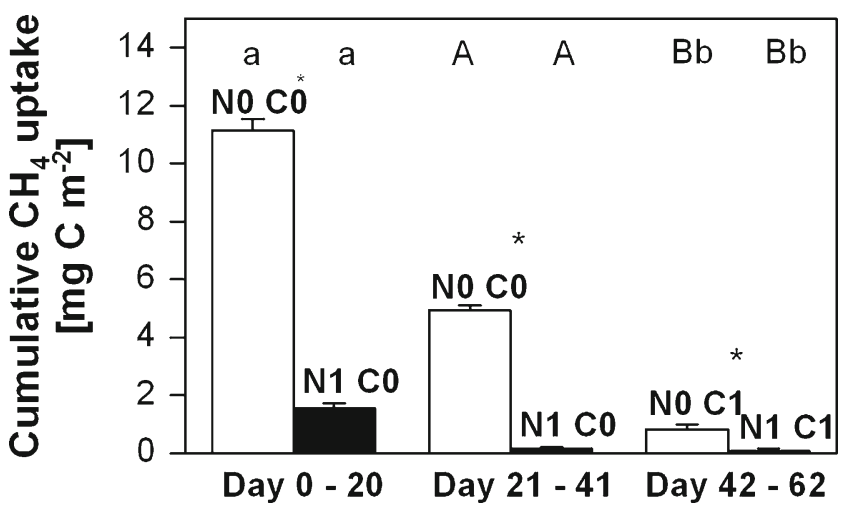

Fig. 2 Calculated cumulative $\mathrm{CH}_{4}$ uptake in the different treatments during 20 days in the first, second or third phase of the experiment. Treatment acronyms are: $N O=$ no $\mathrm{NO}_{3}{ }^{-}$fertilisation, $\mathrm{Nl}=\mathrm{NO}_{3}{ }^{-}$fertilisation $\left(200 \mathrm{~kg} \mathrm{~N} \mathrm{ha}^{-1}\right.$ as $\left.\mathrm{KNO}_{3}\right), C 0=$ no glucose addition, $C 1=$ glucose addition $\left(9,419 \mathrm{~kg} \mathrm{C} \mathrm{ha}^{-1}\right)$. Given are means $\pm 1 \mathrm{SE}$ ( $n=8$ columns per treatment). Asterisks mark significant differences between the $\mathrm{N}$-fertilised and the respective control treatment for each phase $(P<0.05$, Tukey-Kramer test), different lower case letters indicate significant differences between the first and third experimental phases for the columns of the $C 1$ and $C 0$ treatments, and capital letters mark such differences between the second and the third phases $(P<0.05$, paired $t$ test $)$

or disappeared entirely (second phase). After glucose addition, no correlation between $\mathrm{CH}_{4}$ uptake and WFPS was observed irrespective of the $\mathrm{N}$ treatment.

The supplementary experiment with $\mathrm{KNO}_{3}, \mathrm{~K}_{2} \mathrm{SO}_{4}$ or glucose addition showed after 20 days a cumulated $\mathrm{CH}_{4}$ uptake of only $2.86 \pm 0.21 \mathrm{mg} \mathrm{C} \mathrm{m}^{-2}$ in the $\mathrm{KNO}_{3}$ treatment, which is equivalent to about half the rate of the control (5.84 \pm $1.2 \mathrm{mg} \mathrm{C} \mathrm{m}^{-2}$ ). In contrast, the columns treated with $\mathrm{K}_{2} \mathrm{SO}_{4}$ exhibited an enhanced uptake of $7.22 \pm 0.18 \mathrm{mg} \mathrm{C} \mathrm{m}^{-2}$, which was significantly higher than the control (Fig. 4). The glucose application resulted in the smallest cumulated $\mathrm{CH}_{4}$ fluxes of the three treatments $\left(-0.04 \pm 0.27 \mathrm{mg} \mathrm{C} \mathrm{m}^{-2}\right.$, difference significant to the other treatments).

\section{Discussion}

Our study showed that $\mathrm{KNO}_{3}$ relevantly inhibits the $\mathrm{CH}_{4}$ uptake of a temperate deciduous forest soil. We found a significant reduction of the cumulative $\mathrm{CH}_{4}$ uptake by $86 \%$ after a first addition of $\mathrm{KNO}_{3}$ equivalent to $200 \mathrm{~kg} \mathrm{~N} \mathrm{ha}{ }^{-1}$ (10.4 $\mu \mathrm{mol} \mathrm{N} \mathrm{g}{ }^{-1}$ dry soil). A second addition of the same amount of $\mathrm{N}$ induced a further decline to a rate of only $3 \%$ of the control (i.e., a reduction by $97 \%$ ). The effect of $\mathrm{NO}_{3}{ }^{-}$on $\mathrm{CH}_{4}$ uptake was quite variable in earlier field studies and laboratory experiments. Rigler and Zechmeister-Boltenstern (1999) found a stimulation of the $\mathrm{CH}_{4}$ uptake of an acidic spruce forest soil after low inputs of $0.71 \mu \mathrm{mol} \mathrm{N} \mathrm{g}{ }^{-1}$ dry soil under laboratory conditions (which is a 15 th of the $10.4 \mu \mathrm{mol} \mathrm{N} \mathrm{g}{ }^{-1}$ dry soil applied in our study). The authors assumed that $\mathrm{CH}_{4}$ oxidising bacteria may benefit from low $\mathrm{N}$ inputs, overcoming $\mathrm{N}$ limitation of bacterial growth. In contrast, repeated high inputs of a total of 140 and $530 \mathrm{~kg} \mathrm{~N}-\mathrm{NO}_{3}{ }^{-} \mathrm{ha}^{-1}$ showed no effect on $\mathrm{CH}_{4}$ uptake of a boreal spruce forest soil under field conditions (Whalen and Reeburgh 2000). Other field and laboratory approaches support our finding of reduced $\mathrm{CH}_{4}$ uptake as a response to $\mathrm{NO}_{3}{ }^{-}$ addition (Butterbach-Bahl et al. 1998; Reay and Nedwell 2004; Ishizuka et al. 2009). Nitrate amendments from 0.17 to $29.96 \mu \mathrm{mol} \mathrm{N} \mathrm{g}{ }^{-1}$ to soils of temperate mixed hardwood and coniferous forests resulted in a reduction by $10-50 \%$ of the initial $\mathrm{CH}_{4}$ consumption (Wang and Ineson 2003; Xu and Inubushi 2004). A reduction by $86 \%$ and $97 \%$ measured in our study indicates an even more pronounced inhibition of $\mathrm{CH}_{4}$ uptake after two consecutive additions of $10.4 \mu \mathrm{mol} \mathrm{N} \mathrm{g}{ }^{-1}$ dry soil than reported in earlier studies.

Previous studies suggested that the mechanisms of $\mathrm{CH}_{4}$ uptake inhibition in the course of $\mathrm{NO}_{3}{ }^{-}$addition are linked to (a) substrate competition at the enzyme level and (b) noncompetitive effects by the formation of suppressing compounds. High concentrations of $\mathrm{NO}_{2}^{-}$formed after the addition of $\mathrm{NO}_{3}{ }^{-}$are a well-studied inhibiting factor of microbial activity (Bancroft et al. 1979). Principally, the activity of $\mathrm{NO}_{2}^{-}$is relatively high under alkaline $\mathrm{pH}$ conditions, at low temperatures or under anaerobic conditions (van Cleemput and Samater 1995). The forest soil used in this study had a low $\mathrm{pH}$ value of 4.8 , an average temperature of $23^{\circ} \mathrm{C}$, a moisture content of less than $80 \%$ WFPS and contained an $\mathrm{O}_{2}$ concentration close to $210 \mathrm{hPa}$ (data not shown; measured with $\mathrm{O}_{2}$-sensitive micro-optodes, sensor type PSt1 with a resolution between $\pm 0.1 \mathrm{hPa} \mathrm{O}_{2}$ at concentrations of $2 \mathrm{hPa} \mathrm{O}_{2}$ and $\pm 0.87 \mathrm{hPa} \mathrm{O}_{2}$ at concentrations of $207 \mathrm{hPa} \mathrm{O}_{2}$, with a measurement range between 0 and $500 \mathrm{hPa}$, Oxy-10 mini and Microx TX3 devices, PreSens $\mathrm{GmbH}$, Regensburg, Germany). Hence, high levels of $\mathrm{NO}_{2}{ }^{-}$ are not very likely as an inhibiting factor of $\mathrm{CH}_{4}$ oxidation in our study. Several authors suggested that low osmotic potentials or salt effects caused by high cation concentrations might be another possible non-competitive inhibiting factor associated with $\mathrm{N}$ fertilisation (Crill et al. 1994; Hütsch et al. 1994; Bradford et al. 2001a, Bodelier and Laanbroek 2004). A desorption of $\mathrm{NH}_{4}^{+}$from cation exchange sites by high activities of $\mathrm{H}^{+}, \mathrm{Na}^{+}$and $\mathrm{K}^{+}$cations is one possible mechanism reducing $\mathrm{CH}_{4}$ oxidation (King and Schnell 1998), while other authors suggested that a lowered soil water potential is responsible for the inhibiting effect of these cations on $\mathrm{CH}_{4}$ uptake (Nesbit and Breitenbeck 1992; Schnell and King 1996). Wang and Ineson (2003) showed that the effect of $\mathrm{K}_{2} \mathrm{SO}_{4}$ on $\mathrm{CH}_{4}$ uptake by a forest soil was

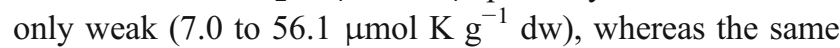
concentration of $\mathrm{KNO}_{3}$ strongly depressed consumption rates (7.1 to $56.2 \mu \mathrm{mol} \mathrm{g}^{-1} \mathrm{dw}$ of $\mathrm{N}$ and $\mathrm{K}$, respectively). In our supplementary experiment, $\mathrm{CH}_{4}$ uptake remained 
Fig. 3 Dependence of $\mathrm{CH}_{4}$ uptake rate on the water-filled pore space in the soil (WFPS) in $\mathrm{N}$-fertilised and unfertilised control columns in the first, second and third phase of the experiment (seven up to 14 measurements per phase in each eight columns per treatment).

Nitrogen was added as $200 \mathrm{~kg} \mathrm{~N} \mathrm{ha}^{-1}\left(\mathrm{KNO}_{3}\right)$ at the beginning of the three phases; in the third phase, glucose $\left(9,419 \mathrm{~kg} \mathrm{C} \mathrm{ha}^{-1}\right)$ was additionally added as a labile $\mathrm{C}$ source
Unfertilised control

N-fertilised

Phase 1 (day 0-20)
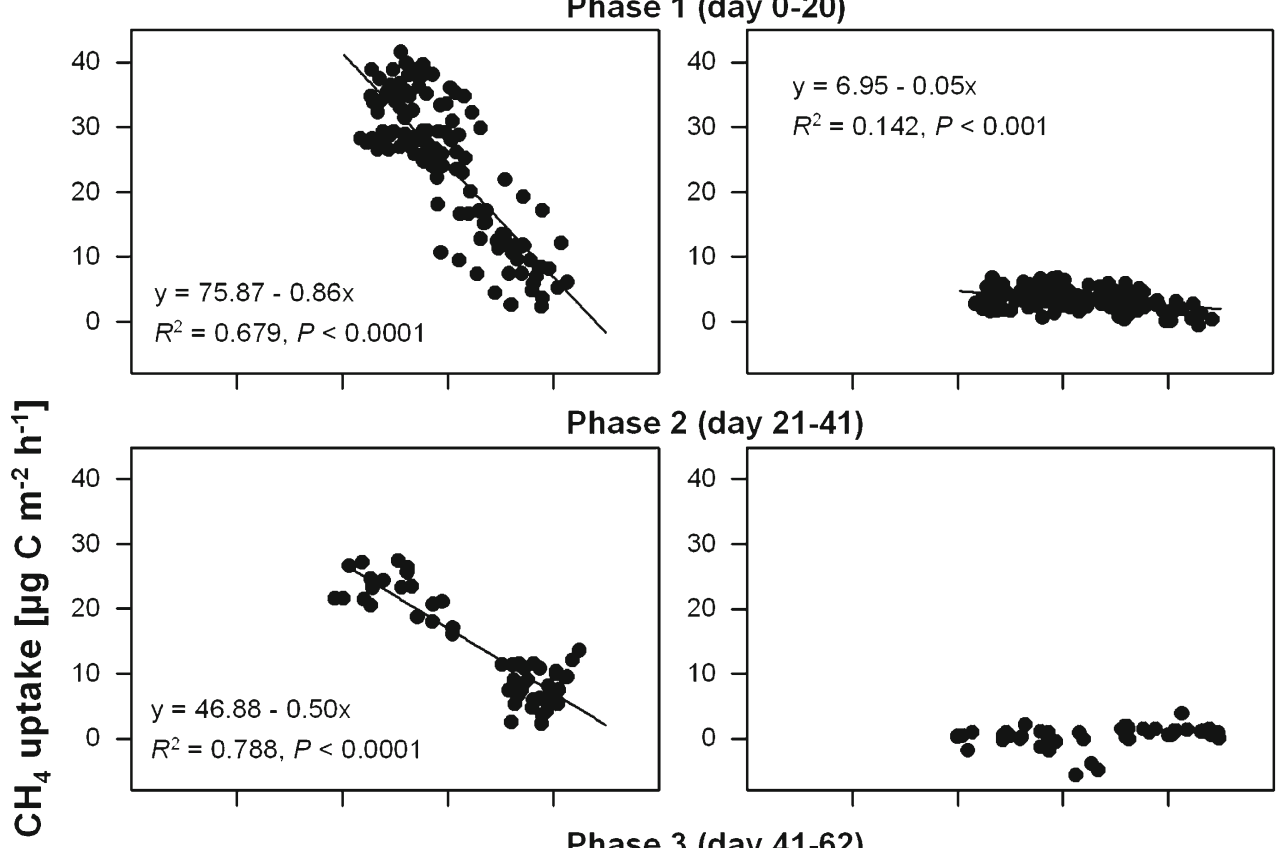

(day 21-41)
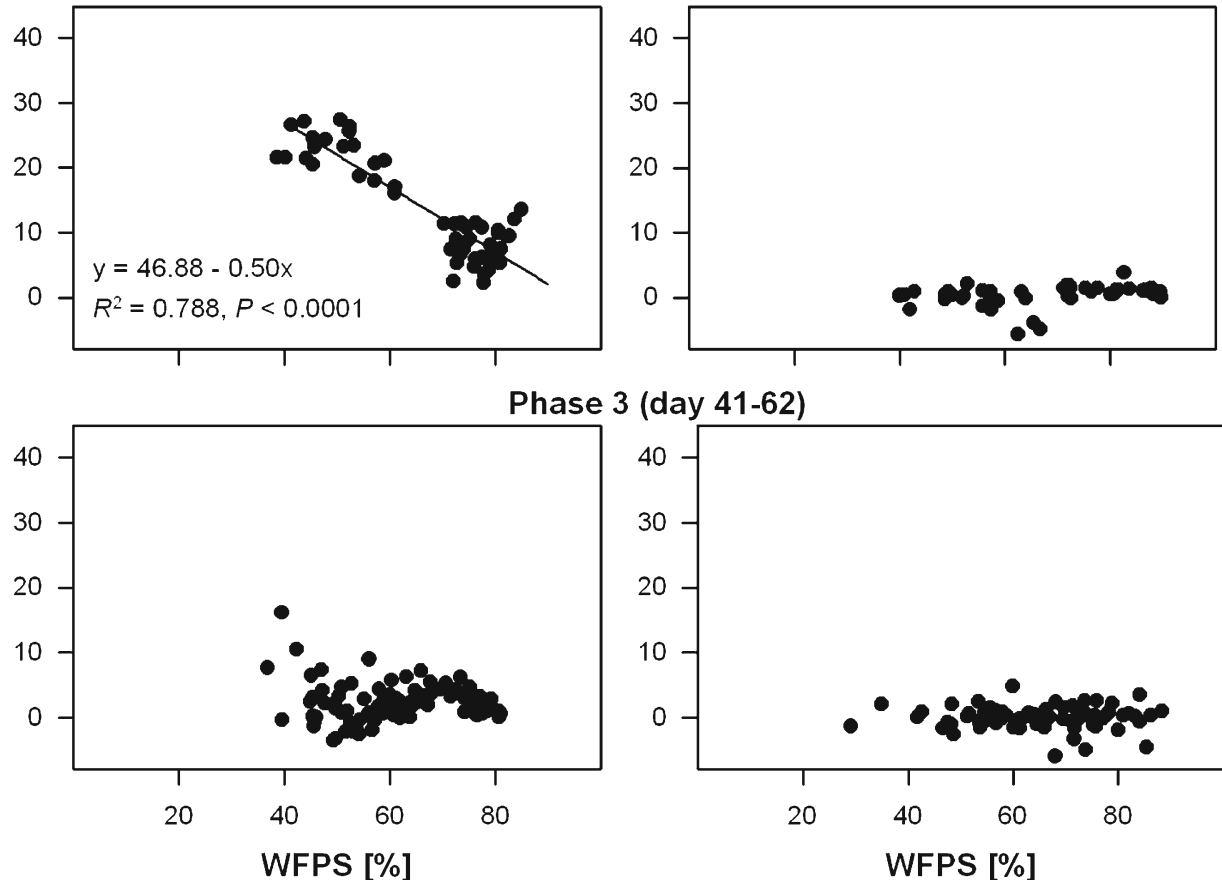

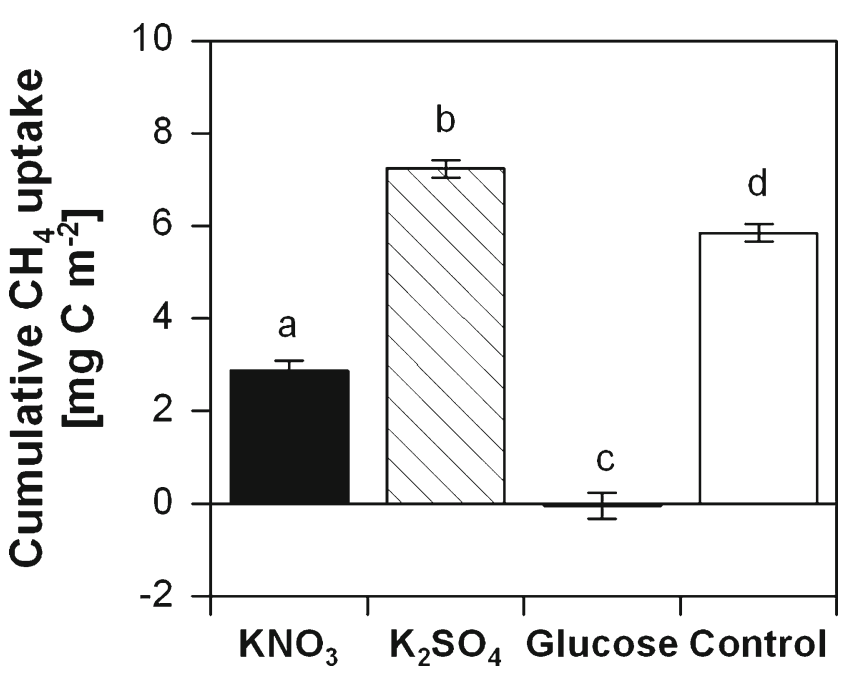

Fig. 4 Calculated cumulative $\mathrm{CH}_{4}$ uptake after the addition of $\mathrm{KNO}_{3}$, $\mathrm{K}_{2} \mathrm{SO}_{4}$ or glucose compared with the control treatment in the supplementary experiment (means $\pm 1 \mathrm{SE}, n=4)$. Lower case letters indicate significant differences between the four treatments $(P<0.05$, Tukey-Kramer test) high after the addition of $10.4 \mu \mathrm{mol} \mathrm{K} \mathrm{g}{ }^{-1} \mathrm{dw}$ in the form of $\mathrm{K}_{2} \mathrm{SO}_{4}$, while the addition of $\mathrm{KNO}_{3}$ with the same amount of $\mathrm{K}$ reduced $\mathrm{CH}_{4}$ uptake by $51 \%$. Thus, a co-determining effect of $\mathrm{K}$ on the reduction of $\mathrm{CH}_{4}$ uptake appears unlikely. The aerobic methanotrophs are a group of methylotrophic bacteria, which are able to use $\mathrm{CH}_{4}$ and other $\mathrm{C} 1$ compounds as their sole energy and $\mathrm{C}$ source (Trotsenko and Murrell 2008; Dedysh and Dunfield 2011). Recent studies also showed the existence of facultative methanotrophy in the genera Methylocystis (Belova et al. 2011; Im and Semrau 2011), Methylocapsa (Dedysh et al. 2005; Dunfield et al. 2010) and Methylocella (Dedysh et al. 2005; Theisen et al. 2005). First analysis of the bacterial community within our soil columns derived from the first phase of the experiment shows the presence of the facultative methanotroph genera Methylocystis, as well as Methylocella and Methylocapsa, but in very low abundances (data not shown). We found Nitrosospira in the unfertilised soils, but not in the fertilised soil indicating another option of $\mathrm{CH}_{4}$ oxidation using $\mathrm{NH}_{4}^{+}$ monooxygenase (Holmes et al. 1995; Kolb et al. 2005, data 
not shown). In our main experiment, the $\mathrm{NH}_{4}^{+}$concentrations increased by $340 \%$ compared with the initial concentration after $\mathrm{N}$ and $\mathrm{C}$ addition and consequently, fertilised columns showed significantly higher $\mathrm{NH}_{4}{ }^{+}$concentrations than the control columns. Similarly, in our supplementary experiment, a single addition of $\mathrm{NO}_{3}{ }^{-}$resulted in by $244 \%$ higher $\mathrm{NH}_{4}{ }^{+}$concentrations. These increases indicate that the frequently observed inhibition by $\mathrm{NH}_{4}{ }^{+}$must also play a key role for the reduction of $\mathrm{CH}_{4}$ uptake in our experiments. Why $\mathrm{NO}_{3}{ }^{-}$addition led to the strong increase in $\mathrm{NH}_{4}{ }^{+}$concentrations remains unclear. Among the possible mechanisms are a stimulation of $\mathrm{N}$ mineralisation by the $\mathrm{NO}_{3}{ }^{-}$pulse (Kuzyakov et al. 2000), the assimilation of $\mathrm{NO}_{3}{ }^{-}$in bacterial biomass and the subsequent release of $\mathrm{NH}_{4}{ }^{+}$after cell death (Cabello et al. 2009), or perhaps dissimilatory $\mathrm{NO}_{3}{ }^{-}$reduction to $\mathrm{NH}_{4}{ }^{+}$in anoxic micro-patches by bacteria.

In general, the WFPS and the $\mathrm{O}_{2}$ content of the soil are recognised to be the main controlling factors of the temporal variation in $\mathrm{CH}_{4}$ uptake (Castro et al. 1995; Bowden et al. 1998). Increased soil water content functions as a physical barrier for $\mathrm{CH}_{4}$ diffusion into the soil, thereby reducing $\mathrm{CH}_{4}$ uptake (Nesbit and Breitenbeck 1992; Castro et al. 1995). In a field study under natural N supply, Guckland et al. (2009) confirmed the tight negative correlation of $\mathrm{CH}_{4}$ uptake and WFPS in the soil of the Hainich forest, where the soil material of our experiment was collected. This negative relation was also found in our experiment under the unfertilised control conditions, but it disappeared with $\mathrm{NO}_{3}{ }^{-}$ addition and its dominant effect on $\mathrm{CH}_{4}$ oxidation (Fig. 3). Guckland et al. (2009) measured hourly $\mathrm{CH}_{4}$ uptake rates of 10 to $30 \mu \mathrm{g} \mathrm{C} \mathrm{m}^{-2} \mathrm{~h}^{-1}$ in the National Park Hainich, where our soil material was collected, during midsummer 2007, when soil temperature was $12-14^{\circ} \mathrm{C}$ and WFPS ranged from $40 \%$ to $70 \%$. Although in our study $\mathrm{CH}_{4}$ uptake of the soil was not investigated under natural conditions, the same range of $\mathrm{CH}_{4}$ uptake was observed (13-33 $\mu \mathrm{g} \mathrm{C} \mathrm{m}{ }^{-2} \mathrm{~h}^{-1}$, when WFPS ranged from $40 \%$ to $70 \%$ as well).

Our experiment evidenced not only the strong inhibiting effect of $\mathrm{NO}_{3}{ }^{-}$on $\mathrm{CH}_{4}$ oxidation but also a negative effect by an added labile $\mathrm{C}$ compound. With the addition of $576 \mu \mathrm{mol} \mathrm{C} \mathrm{g}{ }^{-1} \mathrm{dw}$ soil in the form of glucose, the $\mathrm{CH}_{4}$ uptake of unfertilised soil declined by $83 \%$; adding glucose to $\mathrm{NO}_{3}{ }^{-}$-fertilised soil caused a reduction by $54 \%$ of the initial cumulative $\mathrm{CH}_{4}$ uptake under $\mathrm{NO}_{3}{ }^{-}$fertilisation in the second phase. The repression of $\mathrm{CH}_{4}$ uptake by the combined action of added $\mathrm{N}$ and $\mathrm{C}$ was in its absolute amount even larger than the single effects of $\mathrm{N}$ and $\mathrm{C}$. Compared with the control of the second experimental phase with no addition of $\mathrm{N}$ and $\mathrm{C}$, the cumulative $\mathrm{CH}_{4}$ uptake of the soil treated with $\mathrm{NO}_{3}{ }^{-}$and glucose was reduced by $99.4 \%$, more than the $86 \%$ by $\mathrm{N}$ and $83 \%$ by $\mathrm{C}$ addition. To our knowledge, only few studies so far have dealt with the underlying mechanisms of the effect of alternative labile $\mathrm{C}$ sources on $\mathrm{CH}_{4}$ oxidation (i.e., Schnell and King 1995; Benstead et al. 1998). One possible explanation for the inhibition of $\mathrm{CH}_{4}$ uptake by added labile $\mathrm{C}$ sources is the stimulation of heterotrophic microbial processes. We measured an increasing rate of $\mathrm{N}$ cycling after the addition of glucose, especially in the treatment with $\mathrm{NO}_{3}{ }^{-}$addition where the emission of $\mathrm{N}_{2} \mathrm{O}$ was strongly enforced. Nitrate-reducing microorganisms must have been abundant in the soil microbial community in the N1C1 treatment while other processes such as methanotrophy were apparently suppressed. Facultative $\mathrm{CH}_{4}$ oxidizers are capable of utilising multicarbon compounds, as acetate, succinate, pyruvate, malate or ethanol as their sole $\mathrm{C}$ and energy source (Dedysh and Dunfield 2011). Thus, the obvious suppression of $\mathrm{CH}_{4}$ uptake in the last phase of our experiment could be the consequence of a shift in preference of the methylotrophic bacteria from $\mathrm{CH}_{4}$ to another multicarbon or C1 substrate, as acetate, pyruvate, ethanol or other sideproducts of glucose-utilising bacteria. The two enzymes responsible for the oxidation of $\mathrm{CH}_{4}$ are the particulate and the soluble $\mathrm{CH}_{4}$ monooxygenase (pMMO and sMMO). The genus Methylocella owns only sMMO, which is repressed in the presence of preferred $\mathrm{C}$ sources as acetate, malate or other multicarbon substrates (Theisen et al. 2005). In the case of the genera Methylocapsa and Methylacystis, which prefer $\mathrm{CH}_{4}, \mathrm{pMMO}$ and sMMO are present and not repressed in the presence of other $\mathrm{C}$ compounds (Dedysh and Dunfield 2011). Finally, we cannot exclude that the apparent low $\mathrm{CH}_{4}$ uptake rate observed in the $\mathrm{N} 1 \mathrm{C} 1$ treatment is partly caused by enhanced $\mathrm{CH}_{4}$ production because the addition of suitable $\mathrm{C}$ substrates may increase methanogenesis under anaerobic conditions (Topp and Pattey 1997; Dalal et al. 2007, Win et al. 2010, Sasada et al. 2011). In fact, the soil moisture conditions in our experiment (40-80 \% WFPS) do not exclude the possibility that methanogenesis took place in anaerobic microsites of the not water-saturated soil (Kotiaho et al. 2010). In conclusion, our results suggest that $\mathrm{NO}_{3}{ }^{-}$and labile $\mathrm{C}$ compounds are agents that may significantly affect $\mathrm{CH}_{4}$ uptake in temperate forest soils, in addition to the known factors temperature, WFPS and $\mathrm{NH}_{4}{ }^{+}$.

For the coming decades, a significant rise in temperatures and in the precipitation extremes is predicted for the temperate zone (IPCC 2007). Another important factor will be atmospheric $\mathrm{N}$ deposition, which is expected to remain relatively high in large regions of Central Europe and eastern North America (Galloway et al. 2008). How these expected trends will affect the biogeochemical cycles in forest ecosystems and the chemical state of forest soils is a matter of recent discussion. Much current research focused on alterations of soil $\mathrm{C}$ storage and decomposition processes under changed temperature and $\mathrm{N}$ immission climates (Janssens et al. 2010), but the interaction between $\mathrm{CH}_{4}$ 
uptake and the $\mathrm{C}$ and $\mathrm{N}$ dynamics in forest soils as schematically described in Dubbs and Whalen (2010) has not received much attention yet (Thornton et al. 2007). The suppression of the $\mathrm{CH}_{4}$ oxidising community by increasing $\mathrm{N}$ may last for decades caused by the narrow and slowgrowing community (Bodelier 2011a), so that the $\mathrm{CH}_{4}$ sink of forest soils might be changed in the long-term. For a number of structurally different forest sites in the Hainich forest, Guckland et al. (2009) reported relatively high $\mathrm{CH}_{4}$ uptake rates in the range of 2.0 to $3.4 \mathrm{~kg} \mathrm{C} \mathrm{ha}^{-1}$ year $^{-1}$. Guckland et al. (2009) detected no significant correlation between $\mathrm{CH}_{4}$ uptake and the soil content of $\mathrm{C}_{\text {org }}$ and $\mathrm{NO}_{3}{ }^{-}$. However, $\mathrm{N}$ deposition is rather low in the region with $13 \mathrm{~kg} \mathrm{~N} \mathrm{ha}^{-1}$ year $^{-1}$ (Mund 2004) and complementary studies in forest stands with higher $\mathrm{N}$ input are needed to analyse the interaction between soil $\mathrm{C}$ and $\mathrm{N}$ availability and $\mathrm{CH}_{4}$ oxidation under field conditions.

\section{Conclusions}

Our study supports the hypothesis of an inhibition of $\mathrm{CH}_{4}$ uptake by $\mathrm{NO}_{3}{ }^{-}$in a biologically active deciduous forest soil. The inhibition by $\mathrm{NO}_{3}{ }^{-}$was shown to be linked to increasing $\mathrm{NH}_{4}{ }^{+}$concentrations. The hypothesis of unchanged $\mathrm{CH}_{4}$ uptake after addition of high amounts of labile $\mathrm{C}$ was disproved. In contrast, we found a strong inhibiting influence of a labile $\mathrm{C}$ source (glucose) on $\mathrm{CH}_{4}$ uptake. The simultaneous addition of $\mathrm{NO}_{3}{ }^{-}$and a labile $\mathrm{C}$ source showed that the inhibiting effects of $\mathrm{N}$ and $\mathrm{C}$ are more than additive, and the suppression of $\mathrm{CH}_{4}$ uptake by high soil moisture contents is masked by the dominant $\mathrm{N}$ and $\mathrm{C}$ influence on this process. These findings underpin the need to investigate the interactions between the availability of $\mathrm{NO}_{3}{ }^{-}$and labile $\mathrm{C}$ sources on the process of $\mathrm{CH}_{4}$ oxidation in forest soils. Clearly, our results cannot simply be extrapolated to the field situation because we conducted our experiment with $\mathrm{N}$ loads $>200 \mathrm{~kg} \mathrm{ha}^{-1}$, which is much more than the 10 to $70 \mathrm{~kg} \mathrm{~N}$ ha year ${ }^{-1}$ of $\mathrm{N}$ deposition measured currently in temperate European forests (Dise et al. 1998; Holland et al. 2005; Simpson et al. 2006). However, we used artificially high doses of $\mathrm{N}$ and labile $\mathrm{C}$ to demonstrate that the process of $\mathrm{CH}_{4}$ uptake in soils is controlled by a number of additional factors that mostly have been ignored so far. Thus, this process is more difficult to predict under changing climatic and chemical conditions in future than previously thought.

Acknowledgments This study was funded by the Ministry of Science and Culture of Lower Saxony and the "Niedersächsisches Vorab"; the support is gratefully acknowledged. We appreciate the laboratory assistance provided by Klaus Schützenmeister. We are grateful for the very helpful suggestions of the two anonymous reviewers as their comments highly improved the manuscript.

\section{References}

Adamsen APS, King GM (1993) Methane consumption in temperate and subarctic forest soils: rates, vertical zonation, and responses to water and nitrogen. Appl Environ Microbiol 59:485-490

Bancroft K, Grant IF, Alexander M (1979) Toxicity of $\mathrm{NO}_{2}$ : effect of nitrite on microbial activity in an acid soil. Appl Environ Microbiol 38:940-944

Bédard C, Knowles R (1989) Physiology, biochemistry, and specific inhibitors of $\mathrm{CH}_{4}, \mathrm{NH}_{4}^{+}$, and $\mathrm{CO}$ oxidation by methanotrophs and nitrifiers. Microbiol Mol Biol Rev 53:68-84

Belova S, Baani M, Suzina N, Bodelier P, Liesack W, Dedysh S (2011) Acetate utilization as a survival strategy of peat-inhabiting Methylocystis spp. Environ Microbiol Rep 3:36-46

Bender M, Conrad R (1994) Microbial oxidation of methane, ammonium and carbon monoxide, and turnover of nitrous oxide and nitric oxide in soils. Biogeochemistry 27:97-112

Benstead J, King GM, Williams HG (1998) Methanol promotes atmospheric methane oxidation by methanotrophic cultures and soils. Appl Environ Microbiol 64:1091-1098

Bodelier PLE (2011a) Toward understanding, managing, and protecting microbial ecosystems. Front Microbiol. doi:10.3389/ fmicb.2011.00080

Bodelier PLE (2011b) Interactions between nitrogenous fertilizers and methane cycling in wetland and upland soils. Curr Opin Environ Sustainability 3:379-388

Bodelier PLE, Laanbroek HJ (2004) Nitrogen as a regulatory factor of methane oxidation in soils and sediments. FEMS Microbiol Ecol 47:265-277

Borken W, Brumme R (2009) Methane uptake by temperate forest soils. In: Brumme R, Khanna PK (eds) Functioning and management of European beech Ecosystems. Springer Verlag, Berlin Heidelberg, pp 369-385

Bowden RD, Newkirk KM, Rullo GM (1998) Carbon dioxide and methane fluxes by a forest soil under laboratory-controlled moisture and temperature conditions. Soil Biol Biochem 30:15911597

Bradford MA, Ineson P, Wookey PA, Lappin-Scott HM (2001a) The effects of acid nitrogen and acid sulphur deposition on $\mathrm{CH}_{4}$ oxidation in a forest soil: a laboratory study. Soil Biol Biochem 33:1695-1702

Bradford MA, Wookey P, Ineson P, Lappin-Scott H (2001b) Controlling factors and effects of chronic nitrogen and sulphur deposition on methane oxidation in a temperate forest soil. Soil Biol Biochem 33:93-102

Butterbach-Bahl K, Gasche R, Huber C, Kreutzer K, Papen H (1998) Impact of $\mathrm{N}$-input by wet deposition on $\mathrm{N}$-trace gas fluxes and $\mathrm{CH}_{4}$-oxidation in spruce forest ecosystems of the temperate zone in Europe. Atmos Environ 32:559-564

Cabello P, Roldán MD, Castillo F, Moreno-Vivián C (2009) Nitrogen cycle. Encyclopedia of Microbiology 1:299-321

Castro MS, Steudler PA, Melillo JM, Aber JD, Bowden RD (1995) Factors controlling atmospheric methane consumption by temperate forest soils. Global Biogeochem Cycles 9:1-10

Crill PM, Martikainen PJ, Nykänen H, Silvola J (1994) Temperature and $\mathrm{N}$ fertilization effects on methane oxidation in a drained peatland soil. Soil Biol Biochem 26:1331-13393

Crutzen PJ (1991) Methane's sinks and sources. Nature 350:380-381

Curry CL (2007) Modeling the soil consumption of atmospheric methane at the global scale. Global Biogeochem Cycles 21:GB4012. doi:10.1029/2006GB002818

Dalal RC, Allen DE, Livesley SJ, Richards G (2007) Magnitude and biophysical regulators of methane emission and consumption in the Australian agricultural, forest, and submerged landscapes: a review. Plant Soil 309:43-76 
Dedysh SN, Dunfield PF (2011) Facultative and obligate methanotrophs how to identify and differentiate them. Methods Enzymol 495:31-44

Dedysh SN, Knief C, Dunfield PF (2005) Methylocella species are facultatively methanotrophic. J Bacteriol 187:4665-4670

Denman KL, Brasseur G, Chidthaisong A, Ciais P, Cox PM, Dickinson RE, Hauglustaine D, Heinze C, Holland E, Jacob D, Lohmann U, Ramachandran S, da Silva Dias PL, Wofsy SC, Zhang X (2007) Couplings between changes in the climate system and biogeochemistry. Cambridge University Press, Cambridge, United Kingdom and New York, NY, USA

De Vries W, Solberg S, Dobbertin M, Sterba H, Laubhann D, van Oijen M, Evans C, Gundersen P, Kros J, Wamelink GWW, Reinds GJ, Sutton MA (2009) The impact of nitrogen deposition on carbon sequestration by European forests and heathlands. Forest Ecol Manag 258:1814-1823

Dezi S, Medlyn BE, Tonon G, Magnani F (2010) The effect of nitrogen deposition on forest carbon sequestration: a model-based analysis. Global Change Biol 16:1470-1486

Dise NB, Matzner E, Gundersen P (1998) Synthesis of nitrogen pools and fluxes from European forest ecosystems. Water Air Soil Poll 105:143-154

Dobbie KE, Smith KA (1996) Comparison of $\mathrm{CH}_{4}$ oxidation rates in woodland, arable and set aside soils. Soil Biol Biochem 28:13571365

Dubbs LL, Whalen SC (2010) Reduced net atmospheric $\mathrm{CH}_{4}$ consumption is a sustained response to elevated $\mathrm{CO}_{2}$ in a temperate forest. Biol Fertil Soils 46:597-606

Dunfield PF, Belova SE, Vorob'ev EV, Cornish SL, Dedysh SN (2010) Methylocapsa aurea sp. nov., a facultative methanotroph possessing a particulate methane monooxygenase, and emended description of the genus Methylocapsa. Int J Syst Evol Microbiol 60:2659-2664

Dunfield P, Knowles R (1995) Kinetics of inhibition of methane oxidation by nitrate, nitrite, and ammonium in a humisol. Appl Environ Microbiol 61:3129-3135

Dutaur L, Verchot LV (2007) A global inventory of the soil $\mathrm{CH}_{4}$ sink. Global Biogeochem Cycles 21:GB4013. doi:10.1029/ 2006GB002734

Forster P, Ramaswamy V, Artaxo P, Bertsen T, Betts R, Fahey DW, Haywood J, Lean J, Lowe DC, Myhre G, Nganga J, Prinn R, Raga G, Schulz M, Van Dorland R (2007) Changes in atmospheric constituents and in radiative forcing. Cambridge University Press, Cambridge, United Kingdom and New York, NY, USA, IPCC

Galloway JN, Cowling EB (2002) Reactive nitrogen and the world: 200 years of change. Ambio 31:64-71

Galloway JN, Townsend AR, Erisman JW, Bekunda M, Cai Z, Freney JR, Martinelli LA, Seitzinger SP, Sutton MA (2008) Transformation of the nitrogen cycle: recent trends, questions, and potential solutions. Science 320:889-892

Goldman MB, Groffman PM, Pouyat RV, McDonnell MJ, Pickett STA (1995) $\mathrm{CH}_{4}$ uptake and $\mathrm{N}$ availability in forest soils along an urban to rural gradient. Soil Biol Biochem 27:281-286

Guckland A, Flessa H, Prenzel J (2009) Controls of temporal and spatial variability of methane uptake in soils of a temperate deciduous forest with different abundance of European beech (Fagus sylvatica L.). Soil Biol Biochem 41:1659-1667

Gulledge J, Schimel JP (1998) Low-concentration kinetics of atmospheric $\mathrm{CH}_{4}$ oxidation in soil and mechanism of $\mathrm{NH}_{4}^{+}$inhibition. Appl Environ Microbiol 64:4291-4298

Holland EA, Braswell BH, Sulzman J, Lamarque J-F (2005) Nitrogen deposition onto the United States and Western Europe: synthesis of observations and models. Ecol Appl 15:38-57

Holland EA, Dentener FJ, Braswell BH, Sulzman JM (1999) Contemporary and pre-industrial global reactive nitrogen budgets. Biogeochemistry 46:7-43
Holmes AJ, Costello A, Lidstrom ME, Murrell JC (1995) Evidence that particulate methane monooxygenase and ammonia monooxygenase may be evolutionarily related. FEMS Microbiol Lett 132:203-208

Hütsch BW, Webster CP, Powlson DS (1994) Methane oxidation in soil as affected by land use, soil $\mathrm{pH}$ and $\mathrm{N}$ fertilization. Soil Biol Biochem 26:1613-1622

Im J, Semrau JD (2011) Pollutant degradation by a Methylocystis strain SB2 grown on ethanol: bioremediation via facultative methanotrophy. FEMS Microbiol Lett 318:137-142

IPCC (2007) Climate change 2007: Synthesis report. Contribution of working groups I, II and III to the fourth assessment report of the Intergovernmental Panel on Climate Change. IPCC, Geneva, Switzerland

Ishizuka S, Sakata T, Sawata S, Ikeda S, Sakai H, Takenaka C, Tamai N, S-ichi O, Shimizu T, Kan-na K, Tanaka N, Takahashi M (2009) Methane uptake rates in Japanese forest soils depend on the oxidation ability of topsoil, with a new estimate for global methane uptake in temperate forest. Biogeochemistry 92:281-295

IUSS Working Group WRB (2007) World reference base for soil resources 2006, first update 2007. FAO, Rome

Jang I, Lee S, Hong J-H, Kang H (2006) Methane oxidation rates in forest soils and their controlling variables: a review and a case study in Korea. Ecol Res 21:849-854

Janssens IA, Dieleman W, Luyssaert S, Subke J-A, Reichstein M, Ceulemans R, Ciais P, Dolman AJ, Grace J, Matteucci G, Papale D, Piao SL, Schulze E-D, Tang J, Law BE (2010) Reduction of forest soil respiration in response to nitrogen deposition. Nature Geosci 3:315-322

Kasimir-Klemedtsson Å, Klemedtsson L, Berglund K, Martikainen P, Silvola J, Oenema O (1997) Greenhouse gas emissions from farmed organic soils: a review. Soil Use Manage 13:245-250

King GM, Schnell S (1998) Effects of ammonium and non-ammonium salt additions on methane oxidation by Methylosinus trichosporium $\mathrm{OB} 3 \mathrm{~b}$ and Maine forest soils. Appl Environ Microbiol 64:253-257

King GM, Schnell S (1994a) Effect of increasing atmospheric methane concentration on ammonium inhibition of soil methane consumption. Nature 370:282-284

King GM, Schnell S (1994b) Ammonium and nitrite inhibition of methane oxidation by Methylobacter albus BG8 and Methylosinus trichosporium $\mathrm{OB} 3 \mathrm{~b}$ at low methane concentrations. Appl Environ Microbiol 60:3508-3513

Kolb S, Knief C, Dunfield PF, Conrad R (2005) Abundance and activity of uncultured methanotrophic bacteria involved in the consumption of atmospheric methane in two forest soils. Environ Microbiol 7:1150-1161

Kotiaho M, Fritze H, Merilä P, Juottonen H, Leppälä M, Laine J, Laiho R, Yrjälä K, Tuittila E-S (2010) Methanogen activity in relation to water table level in two boreal fens. Biol Fertil Soils 46:567-575

Kuzyakov Y, Friedel J, Stahr K (2000) Review of mechanisms and quantification of priming effects. Soil Biol Biochem 32:1485-1498

Le Mer J, Roger P (2001) Production, oxidation, emission and consumption of methane by soils: A review. Eur J Soil Biol 37:25-50

Liu L, Greaver TL (2009) A review of nitrogen enrichment effects on three biogenic GHGs: the $\mathrm{CO}_{2}$ sink may be largely offset by stimulated $\mathrm{N}_{2} \mathrm{O}$ and $\mathrm{CH}_{4}$ emission. Ecol Lett 12:1103-1117

Loftfield N, Flessa H, Augustin J, Beese F (1997) Automated gas chromatographic system for rapid analysis of the atmospheric trace gases methane, carbon dioxide, and nitrous oxide. J Environ Qual 26:560-564

MacDonald JA, Skiba U, Sheppard LJ, Ball B, Roberts JD, Smith KA, Fowler D (1997) The effect of nitrogen deposition and seasonal variability on methane oxidation and nitrous oxide emission rates in an upland spruce plantation and moorland. Atmos Environ 31:3693-3706 
Magnani F, Mencuccini M, Borghetti M, Berbigier P, Berninger F, Delzon S, Grelle A, Hari P, Jarvis PG, Kolari P, Kowalski AS, Lankreijer H, Law BE, Lindroth A, Loustau D, Manca G, Moncrieff JB, Rayment M, Tedeschi V, Valentini R, Grace J (2007) The human footprint in the carbon cycle of temperate and boreal forests. Nature 447:848-850

Mancinelli RL (1995) The regulation of methane oxidation in soil. Annu Rev Microbiol 49:581-605

Mund M (2004) Carbon pools of European beech forests (Fagus sylvatica) under different silvicultural management. $\mathrm{PhD}$ thesis, Faculty of Forestry and Forest Ecology, University of Göttingen

Nadelhoffer KJ, Emmett BA, Gundersen P, Kjonaas OJ, Koopmans CJ, Schleppi P, Tietema A, Wright RF (1999) Nitrogen deposition makes a minor contribution to carbon sequestration in temperate forests. Nature 398:145-148

Nesbit SP, Breitenbeck GA (1992) A laboratory study of factors influencing methane uptake by soils. Agr Ecosyst Environ 41:39-54

Priemé A, Christensen S (1997) Seasonal and spatial variation of methane oxidation in a Danish spruce forest. Soil Biol Biochem 29:1165-1172

Reay DS, Nedwell DB (2004) Methane oxidation in temperate soils: effects of inorganic N. Soil Biol Biochem 36:2059-2065

Rigler E, Zechmeister-Boltenstern S (1999) Oxidation of ethylene and methane in forest soils-effect of $\mathrm{CO}_{2}$ and mineral nitrogen. Geoderma 90:147-159

Sasada Y, Win KT, Nonaka R, Win AT, Toyota K, Motobayashi T, Hosomi M, Dingjiang C, Lu J (2011) Methane and $\mathrm{N}_{2} \mathrm{O}$ emissions, nitrate concentrations of drainage water, and zinc and copper uptake by rice fertilized with anaerobically digested cattle or pig slurry. Biol Fertil Soils 47:949-956

Schlichting E, Blume H-P, Stahr K (1995) Bodenkundliches PraktikumEine Einführung in pedologisches Arbeiten für Ökologen, insbesondere Land- und Forstwirte und für Geowissenschaftler. Blackwell Wissenschaft, Berlin

Schnell S, King G (1996) Responses of methanotrophic activity in soils and cultures to water stress. Appl Environ Microbiol 62:3203-3209

Schnell S, King GM (1995) Stability of methane oxidation capacity to variations in methane and nutrient concentrations. FEMS Microbiol Ecol 17:285-294

Simpson D, Butterbach-Bahl K, Fagerli H, Kesik M, Skiba U, Tang S (2006) Deposition and emissions of reactive nitrogen over European forests: a modelling study. Atmos Environ 40:5712-5726
Smith KA, Dobbie KE, Ball BC, Bakken LR, Sitaula BK, Hansen S, Brumme R, Borken W, Christensen S, Priemé A, Fowler D, Macdonald JA, Skiba U, Klemedtsson L, Kasimir-Klemedtsson A, Degórska A, Orlanski P (2000) Oxidation of atmospheric methane in Northern European soils, comparison with other ecosystems, and uncertainties in the global terrestrial sink. Global Change Biol 6:791-803

Steinkamp R, Butterbach-Bahl K, Papen H (2001) Methane oxidation by soils of an $\mathrm{N}$ limited and $\mathrm{N}$ fertilized spruce forest in the Black Forest, Germany. Soil Biol Biochem 33:145-153

Theisen AR, Ali MH, Radajewski S, Dumont MG, Dunfield PF, McDonald IR, Dedysh SN, Miguez CB, Murrell JC (2005) Regulation of methane oxidation in the facultative methanotroph Methylocella silvestris BL2. Mol Microbiol 58:682-692

Thornton PE, Lamarque JF, Rosenbloom NA, Mahowald NM (2007) Influence of carbon-nitrogen cycle coupling on land model response to $\mathrm{CO}_{2}$ fertilization and climate variability. Global Biogeochem Cycles 21:GB4018. doi: 10.1029/2006GB002868

Topp E, Pattey E (1997) Soils as sources and sinks for atmospheric methane. Can J Soil Sci 77:167-177

Trotsenko YA, Murrell JC (2008) Metabolic aspects of aerobic obligate methanotrophy. Adv Appl Microbiol 63:183-229

Van Cleemput O, Samater AH (1995) Nitrite in soils: accumulation and role in the formation of gaseous $\mathrm{N}$ compounds. Fert Res 45:81-89

Wang Z-P, Ineson P (2003) Methane oxidation in a temperate coniferous forest soil: effects of inorganic N. Soil Biol Biochem 35:427433

Whalen SC (2000) Influence of $\mathrm{N}$ and non-N salts on atmospheric methane oxidation by upland boreal forest and tundra soils. Biol Fertil Soils 31:279-287

Whalen SC, Reeburgh WS (2000) Effect of nitrogen fertilization on atmospheric methane oxidation in boreal forest soils. Chemosphere 2:151-155

Win KT, Nonaka R, Toyota K, Motobayashi T, Hosomi M (2010) Effects of option mitigating ammonia volatilization on $\mathrm{CH}_{4}$ and $\mathrm{N}_{2} \mathrm{O}$ emissions from a paddy field fertilized with anaerobically digested cattle slurry. Biol Fertil Soils 46:589-595

$\mathrm{Xu}$ X, Inubushi K (2004) Effects of N sources and methane concentrations on methane uptake potential of a typical coniferous forest and its adjacent orchard soil. Biol Fertil Soils 40:215-221 